\title{
GREENHOUSE GASES EMISSIONS RELATED TO SUGARCANE ETHANOL
}

\author{
Joaquim E. A. Seabra, Isaias Carvalho Macedo and \\ Manoel Regis Lima Verde Leal
}

\section{INTRODUCTION}

One of the main objectives of biofuels use is the replacement of fossil fuels, contributing to the reduction of dependency on fossil fuels and mitigation of greenhouse gases (GHG) emissions. But the effectiveness of such substitution depends in the way the biofuel is produced. Since all processing technologies involve direct or indirectly the use of fossil resources, the real benefit of a biofuel depends on the net fossil energy savings resulted from its use, also taking into account the GHG emissions associated to its lifecycle.

The environmental advantages of sugarcanebased ethanol, regarding gasoline substitution and GHG emissions mitigation, have been acknowledged since the first comprehensive energy balance and GHG emissions studies were available (Silva et al., 1978; Macedo and Nogueira, 1985; Macedo, 1992). Updating studies have been published since then (Macedo, 1998; Macedo et al., 2004), following the changes in the sugarcane sector and the new parameters for environmental analysis. But the rapid growth of the cane sector in Brazil in the last decade, associated to some legal constraints and technology development are changing important parameters in this evaluation. New cane varieties and productivity, the legal restrictions to sugarcane burning practice and the increased mechanization influence the energy and emissions balance in different ways. Furthermore, cane mills started a strong action in selling electricity surplus, and the use of portion of the cane trash for energy will be seen in the next years. Finally, the ethanol use technology has changed, with the growing fleet of flexible-fuel vehicles.

Recent works (Macedo et al., 2008; Macedo and Seabra, 2008) evaluated the energy balance and GHG emissions for the current situation and for projected scenarios, considering the effects of employment of different technologies in the sugarcane sector. This chapter reports the main results of these studies, as well as the results presented by the main international initiatives promoting the use of biofuels. A brief discussion about the potential of mitigation associated to the Brazilian ethanol is also presented.

\section{ENERGY BALANCE AND GHG EMISSIONS IN ETHANOL LIFECYCLE}

Macedo and Seabra (2008) evaluated the energy balance and GHG emissions of the sugarcane sector in 2006 and the expected changes for 2020 , considering the effects of the employment of different technologies. Two scenarios were evaluated in the future case: one based on the maximum electricity generation through steam cycles (2020 Electricity scenario), and a second one based on the ethanol production from biochemical conversion of the surplus ligno-cellulosic material (2020 Ethanol scenario). In both scenarios, $40 \%$ of the trash available in the field would be collected to be used as energy source at the mill.

The 2006 results are based on 2005/2006 average conditions, with the best available and comprehensive data from the Brazilian CenterSouth Region (Macedo et al., 2008). Note that 
GHG emissions/mitigation are evaluated for each Scenario specific conditions; scenario implementation schedules are not presented (or needed) for the objective of this kind of study.

However, it must be said that the Electricity Scenario implementation is occurring now in all Greenfield operations, and already in some retrofit of existing units. The Ethanol Scenario, as proposed, still depends on technological development of the biomass hydrolysis/fermentation processes, and it would take longer to be implemented to a significant level in the context of the Brazilian ethanol production (Seabra, 2008).

The data used for 2006 is for a sample of 44 mills (100 M t cane/season), all in the Brazilian Center South. Data have been collected/processed for the last 15 years, for agriculture and industry, for the CTC "mutual benchmarking". The 2020 parameters are authors' projections, based on cane specialists' estimations, while industrial parameters are simulation results, using parameters from the literature.
The systems boundaries considered for the energy flows and GHG emissions and mitigation include sugarcane production, cane transportation to the industrial conversion unit, the industrial unit, ethanol transportation to the gas/petrol station, and vehicle engine performance. Emissions from direct energy use were considered, as well as emissions from cane trash burning in the field and soil emissions, derived from fertilizers application, limestone and residues returned to the soil (stillage, filtercake and cane trash). Emissions mitigation was assessed considering the substitution of ethanol, surplus bagasse and electricity respectively for gasoline, fuel oil and natural gas thermoelectricity.

The results for energy balance and emissions are presented in Tables 1 and 2, respectively. Note that the differences in total emissions are strongly dependent on the co-products credits. The complete elimination of trash burning practice in the 2020 is an important aspect, but the major difference between 2006 and the 2020 scenarios

TABLE 1 Energy balance in anhydrous ethanol production (MJ/t cane) .

\begin{tabular}{|c|c|c|c|}
\hline & 2006 & 2020 Electricity & 2020 Ethanol \\
\hline Fossil energy input & 235 & 262 & 268 \\
\hline Cane production & 211 & 238 & 238 \\
\hline Cane farming & 109 & 142 & 143 \\
\hline Agr. inputs & 65 & 51 & 50 \\
\hline Transportation & 37 & 45 & 45 \\
\hline Ethanol production & 24 & 24 & 31 \\
\hline Chemicals & 19 & 20 & 25 \\
\hline Equip. and buildings & 5 & 4 & 6 \\
\hline Renewable energy output & 2,198 & 3,171 & 3,248 \\
\hline Ethanol $^{a}$ & 1,926 & 2,060 & 2,880 \\
\hline Electricity surplus ${ }^{\mathrm{b}}$ & 96 & 1,111 & 368 \\
\hline Bagasse surplus ${ }^{a}$ & 176 & 0 & 0 \\
\hline Energy ratio & 9.4 & 12.1 & 12.1 \\
\hline
\end{tabular}

a Based on LHV (Low Heating Value).

b Considering the substitution of biomass-electricity for natural gas-electricity, generated with $40 \%$ (2006) and 50\% (2020) efficiencies (LHV). 
TABLE 2 Total emissions in ethanol life cycle ( $\mathrm{kg} \mathrm{CO} \mathrm{Ce}_{2} / \mathrm{m}^{3}$ anhydrous) ${ }^{\mathrm{a}}$.

\begin{tabular}{|c|c|c|c|}
\hline & 2006 & 2020 Electricity & 2020 Ethanol \\
\hline Cane production & 417 & 326 & 232 \\
\hline Farming & 97 & 117 & 91 \\
\hline Agr. inputs & 57 & 43 & 23 \\
\hline Transportation & 32 & 37 & 26 \\
\hline Trash burning & 84 & 0 & 0 \\
\hline Soil emissions & 146 & 129 & 92 \\
\hline Ethanol production & 25 & 24 & 22 \\
\hline Chemicals & 21 & 20 & 19 \\
\hline Equip. and buildings & 4 & 4 & 3 \\
\hline Ethanol distribution & 51 & 43 & 43 \\
\hline \multicolumn{4}{|l|}{ Credits } \\
\hline Electricity surplus ${ }^{\mathrm{b}}$ & -74 & -803 & -190 \\
\hline Bagasse surplus ${ }^{c}$ & -150 & 0 & 0 \\
\hline Total & 269 & -409 & 107 \\
\hline
\end{tabular}

a Emissions for hydrous ethanol $/ \mathrm{m}^{3}$ are about $5 \%$ less than values verified for anhydrous ethanol.

b Considering the substitution of biomass-electricity for natural gas-electricity, generated with $40 \%$ (2006) and 50\% (2020) efficiencies (LHV).

c Considering the substitution of biomass fuelled boilers (efficiency $=79 \%$; LHV) for oil fuelled boilers (efficiency $=92 \%$; LHV).

is due to an actual increase in the system energy efficiency (greater energy output).

This indicates the importance of the better use of sugarcane's energy for further improvements of the already huge potential of ethanol as a good al- ternative for GHG emissions mitigation. It is worth mentioning that other more efficient technology routes for biomass use will raise in the future, which may lead to even greater environmental benefits related to cane ethanol (see Chapter 18, Part 4).

TABLE 3 Avoided emissions due to ethanol use (t $\mathrm{CO}_{2} \mathrm{eq} / \mathrm{m}^{3}$ anhydrous or hydrous).

\begin{tabular}{|l|c|c|c|}
\hline \multirow{3}{*}{2006} & Ethanol use $^{\mathbf{a}}$ & Avoided emissions $^{\mathbf{b}}$ & Net emissions $^{\mathbf{c}}$ \\
\hline \multirow{3}{*}{2020 Electricity } & E100 & -2.0 & -1.7 \\
\cline { 2 - 4 } & E25 & -2.1 & -1.8 \\
\hline \multirow{3}{*}{2020 Ethanol } & E100 & -2.0 & -2.4 \\
\cline { 2 - 4 } & FFV & -1.8 & -2.5 \\
\cline { 2 - 4 } & E25 & -2.1 & -1.9 \\
\cline { 2 - 4 } & E100 & -2.0 & -1.7 \\
\cline { 2 - 4 } & FFV & -1.8 & -2.0 \\
\hline
\end{tabular}

a E100, or HDE: hydrous ethanol in dedicated engines; FFV: hydrous ethanol in flex-fuel engines; E25: anhydrous ethanol (25\% volume) and gasoline blend.

b Avoided emission (negative values) due to the substitution of ethanol for gasoline; fuel equivalencies verified for each application in Brazil (MACEDO et al., 2008).

c Net emission = (avoided emission due to ethanol use) + (ethanol life cycle emission). Co-products credits are included. 


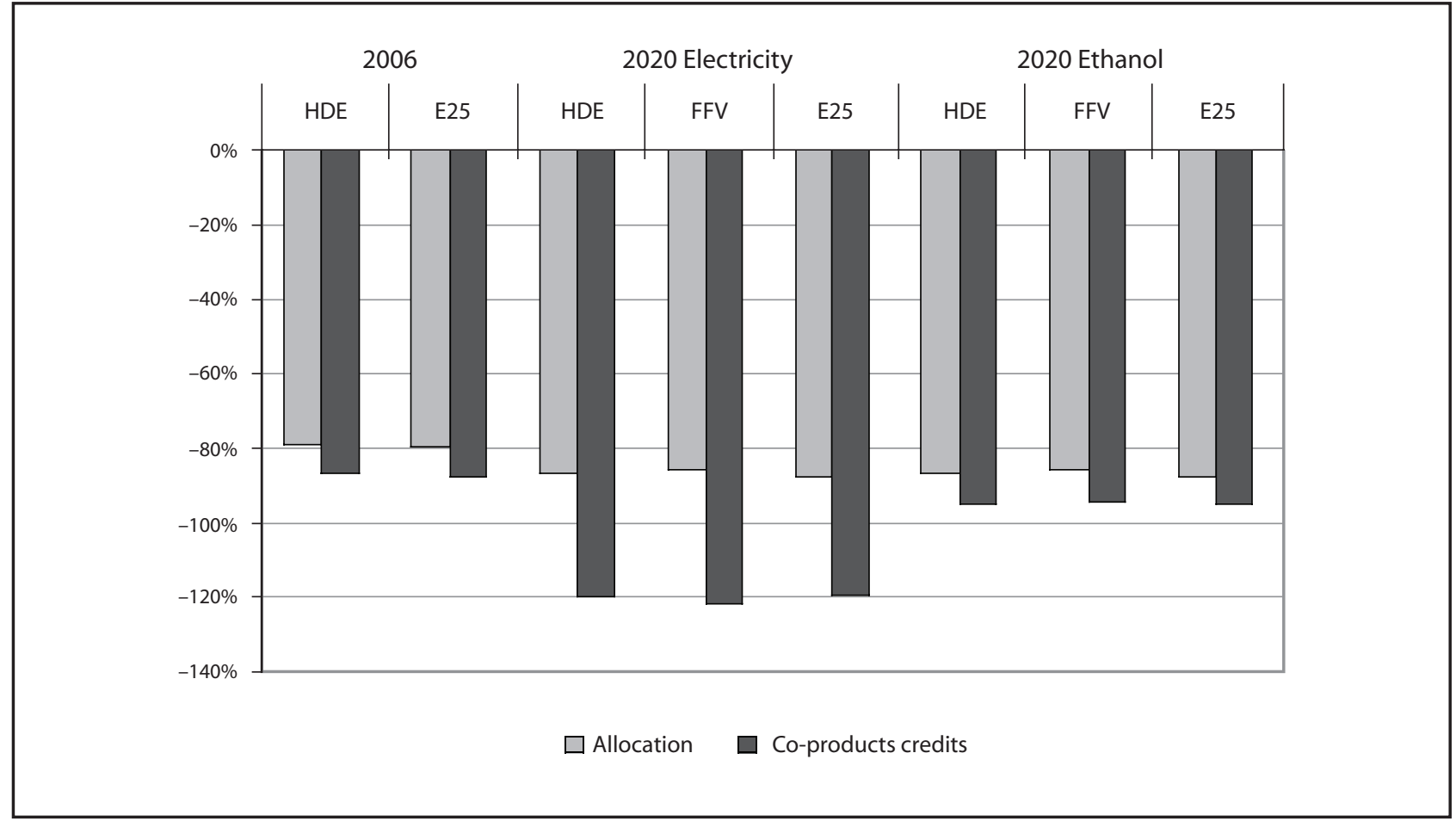

FIGURE 1 GHG mitigation with respect to gasoline: allocation or co-products credits.

GHG emissions mitigation with respect to gasoline is presented in Figure 1, for the different ethanol uses in Brazil. The figure also shows the impacts of emissions allocation (based on energy content of the co-products) in comparison to the substitution criterion for ethanol co-products credits evaluation. The detailed results using the substitution criterion is presented in Table 3.

$\mathrm{CO}_{2}$ emissions due the direct land use change were assessed in the study as well, using the cane expansion analysis presented by Nassar et al. (2008), data for soil carbon stocks from Amaral et $a l$. (2008) and the IPCC methodology to estimate land use change emissions. As indicated in Table 4, negative emissions were verified in all scenarios, due to the increase of soil carbon stocks. This was expected, since the expansion areas for sugarcane include a very small fraction of native lands with high carbon stocks, and some degraded land (Macedo and Seabra, 2008). As for the indirect land use change effects, the authors suggest that within its soil and climate limitations, the strict application of the environmental legislation for the new units, and the relatively small areas needed
( 5 Mha, until 2020), the expansion of sugarcane until 2020 is not expected to contribute to ILUC emissions. More details about the indirect land use change is presented in Chapter 11 .

\section{INTERNATIONAL ANALYSIS}

Even though there is no consensus on the basic principles about the sustainability of biofuels, the need to lead to GHG emissions reduction (compared to the equivalent fossil option) is one of the most relevant aspects. With such goal, international initiatives aimed at promoting the use of biofuels have been established in different countries, paying attention to other sustainability criteria as well. In this section we present the analyses of the main international programs on the GHG emissions related to the sugarcane ethanol life cycle.

\section{EU Directive}

The European Union Directive on the promotion of the use of energy from renewable sources established a mandatory target of a $20 \%$ share of energy from renewable sources in overall Commu- 
TABLE 4 Emissions associated with LUC to unburned cane.

\begin{tabular}{|c|c|c|c|c|}
\hline \multirow[t]{2}{*}{ Reference crop } & \multirow{2}{*}{$\frac{\text { Carbon stock change }^{\mathrm{a}}}{\text { (t C/ha) }}$} & \multicolumn{3}{|c|}{ Emissions (kg CO $2 \mathrm{eq} / \mathrm{m}^{3}$ ) } \\
\hline & & 2006 & 2020 Electricity & 2020 Ethanol \\
\hline Degraded pasturelands & 10 & -302 & -259 & -185 \\
\hline Natural pasturelands & -5 & 157 & 134 & 96 \\
\hline Cultivated pasturelands & -1 & 29 & 25 & 18 \\
\hline Soybean cropland & -2 & 61 & 52 & 37 \\
\hline Maize cropland & 11 & -317 & -272 & -195 \\
\hline Cotton cropland & 13 & -384 & -329 & -236 \\
\hline Cerrado & -21 & 601 & 515 & 369 \\
\hline Campo limpo & -29 & 859 & 737 & 527 \\
\hline Cerradão & -36 & 1040 & 891 & 638 \\
\hline LUC emissions $^{\mathrm{b}}$ & & -118 & -109 & -78 \\
\hline
\end{tabular}

a Based on measured values for below and above ground (only for perennials) carbon stocks.

b Considering the following LUC distribution - 2006: $50 \%$ pasturelands ( $70 \%$ degraded pasturelands; $30 \%$ natural pasturelands), $50 \%$ croplands (65\% soybean croplands; $35 \%$ other croplands); $2020: 60 \%$ pasturelands (70\% degraded pasturelands; $30 \%$ natural pasturelands); $40 \%$ croplands (65\% soybean croplands; $35 \%$ other croplands). Cerrados were always less than $1 \%$.

nity energy consumption by 2020, and a 10\% share in transport. According to the sustainability criteria defined by the Directive, the energy from biofuels should be taken into account in the national targets only if the GHG emission saving from their use is at least 35\%, when compared to the equivalent fossil (petrol or diesel). With effect from $1^{\text {st }}$ January 2017, such emissions saving should be at least 50\%, and from 1 January 2018, at least 60\% for biofuels and bioliquids produced in installations in which production started on or after $1^{\text {st }}$ January 2017.

In order to avoid a disproportionate administrative burden, a list of default values was laid down for common biofuel production pathways. For the Brazilian sugarcane ethanol (used in Europe), the default value is $24 \mathrm{~g} \mathrm{CO}_{2} \mathrm{eq} / \mathrm{MJ}$, which leads to an emission saving of $71 \%$ compared to gasoline (see Table 5). The Directive imposes that the land use change emissions should be taken into account, using a proposed methodology. A bonus of $29 \mathrm{~g} \mathrm{CO}_{2} \mathrm{eq} / \mathrm{MJ}$ could be applied if biomass is obtained from restored degraded land under specific conditions provided by the Directive. As for the indirect impacts of the land use change, the Direc- tive states that the Commission should develop a concrete methodology to minimize greenhouse gas emissions caused by indirect land-use changes. To this end, the Commission should analyze the inclusion of a factor for indirect land-use changes in the calculation of greenhouse gas emissions and the need to provide greater incentives to sustainable biofuels which minimize the impacts of land-use change and improve biofuel sustainability with respect to indirect land-use change.

\section{RTFO}

The Renewable Transport Fuels Obligation (RTFO) requires suppliers of fossil fuels to ensure that a specified percentage of the road fuels they supply in the UK is made up of renewable fuels. The target for $2010 / 11$ is $3.5 \%$ by volume. Emissions reductions with respect to the equivalent fossil fuel should be $50 \%$, taking also into account the emissions due to land use change wherever possible. Default values considered for the sugarcane ethanol produced in Brazil and used in Europe are presented in Table 6. 
TABLE 5 EU Directive disaggregated default values for the Brazilian sugarcane ethanol pathway.

\begin{tabular}{|l|c|}
\hline \multicolumn{1}{|c|}{ Step } & \multicolumn{1}{|c|}{$\begin{array}{c}\text { Default value } \\
\text { (g CO } \mathbf{2} \text { eq/MJ) }\end{array}$} \\
\hline Cultivation $\left(\mathrm{e}_{\mathrm{ec}}\right)$ & 14 \\
\hline Processing $\left(\mathrm{e}_{\mathrm{p}}-\mathrm{e}_{\mathrm{ee}}\right)$ & 1 \\
\hline Transport and distribution $\left(\mathrm{e}_{\mathrm{td}}\right)$ & 9 \\
\hline Total & $\mathbf{2 4}$ \\
\hline GHG emission saving & $\mathbf{7 1 \%}$ \\
\hline
\end{tabular}

Source: EU DIRECTIVE, 2009.

\section{CARB}

Through the regulation referred as the California Low Carbon Fuel Standard (LCFS), the Air Resources Board (ARB/Board) staff is proposing to reduce emissions of greenhouse gases by lowering the carbon content of transportation fuels used in California. One standard is established for gasoline and the alternative fuels that can replace it. A second similar standard is set for diesel fuel and its replacements. Each standard is set to achieve an average 10 reduction in the carbon intensity of the statewide mix transportation fuels by 2020. In addition, the LCFS is designed to reduce California's dependence on petroleum, create a lasting market for clean transportation technology, and stimulate the production and use of alternative low-carbon fuels in California. Reformulated gaso-

TABLE 6 Fuel chain summary for Brazilian sugarcane ethanol under the RTFO.

\begin{tabular}{|l|c|}
\hline \multicolumn{1}{|c|}{ Module } & \multicolumn{1}{|c|}{$\begin{array}{c}\text { Carbon intensity } \\
\text { (kg CO } \mathbf{2} \text { eq/t etanol) }\end{array}$} \\
\hline Crop production & 348 \\
\hline Feedstock transport & 49 \\
\hline Conversion & 0 \\
\hline Liquid fuel transport & 93 \\
\hline & 175 \\
\hline Total & $\mathbf{6 6 5}$ \\
\hline
\end{tabular}

Source: RFA, 2008. line mixed with corn-derived ethanol at 10 percent by volume and low sulfur diesel fuel represent the baseline fuels.

Emissions from land use change were included in the evaluation for biofuels. Using the GREET and GTAP (to assess land use changes) models, different biofuels pathways were analyzed. The original pathway document for sugarcane ethanol, published in February 2009, was for baseline ethanol produced in Brazil, transported to and used in California. The emissions were estimated as $27.4 \mathrm{~g} \mathrm{CO}_{2}$ eq/MJ, plus $46 \mathrm{~g} \mathrm{CO}_{2}$ eq/MJ due to land use change (see Table 7). Two other scenarios were later added to the analysis, incorporating issues related to the mechanical harvesting and the electricity co-product credits (see Table 8). Innumerous critics were raised with respect to the land use change analysis, and committees were assembled in order to improve the analysis. In the future new values should be reported by the Board.

\section{EPA}

The Renewable Fuel Standard (RFS) program was created under the Energy Policy Act (EPAct) of 2005, and established the first renewable fuel volume mandate in the United States. The Energy Independence and Security Act of 2007 (EISA) increased the volume of renewable fuel required to be blended into transportation fuel from 9 billion

TABLE 7 GHG emissions summary for sugarcane ethanol.

\begin{tabular}{|l|c|}
\hline \multicolumn{1}{|c|}{ Components } & $\begin{array}{c}\text { GHG emissions } \\
\text { (g CO } \mathbf{2} \text { eq/MJ) }\end{array}$ \\
\hline Sugarcane farming & 9.9 \\
\hline $\begin{array}{l}\text { Ag chemicals production and use } \\
\text { impacts }\end{array}$ & 8.7 \\
\hline Sugarcane transportation & 2.0 \\
\hline Ethanol production & 1.9 \\
\hline Ethanol T\&D & 4.1 \\
\hline LUC & 46 \\
\hline Total & $\mathbf{7 3 . 4}$ \\
\hline
\end{tabular}

a Include emissions from ethanol combustion.

Source: CARB, 2008. 
TABLE 8 Summary of baseline pathway and two additional scenarios.

\begin{tabular}{|l|c|}
\hline \multicolumn{1}{|c|}{ Pathway description } & $\begin{array}{c}\text { WTW GHG emissions } \\
\text { (g CO } \mathbf{2} \text { eq/MJ) }\end{array}$ \\
\hline $\begin{array}{l}\text { Baseline Pathway } \\
\text { Brazilian sugarcane using } \\
\text { average production process }\end{array}$ & 27.40 \\
\hline $\begin{array}{l}\text { Scenario 1 } \\
\text { Brazilian sugarcane with average } \\
\text { production process, mechanized } \\
\text { harvesting and electricity co- } \\
\text { product credit }\end{array}$ & 12.20 \\
\hline $\begin{array}{l}\text { Scenario 2 } \\
\text { Brazilian sugarcane with } \\
\text { average production process and } \\
\text { electricity co-product credit }\end{array}$ & \\
\hline
\end{tabular}

a LUC emissions are not included.

Source: CARB, 2009.

gallons in 2008 to 36 billion gallons by 2022, and established new categories of renewable fuel (conventional and advanced biofuels) and set separate volume requirements for each one. The term advanced biofuel (e.g., ethanol derived from sugar or cellulose) means renewable fuel, other than ethanol derived from corn starch that has lifecycle greenhouse gas emissions and at least 50\% less than baseline lifecycle greenhouse gas emissions.

In the original evaluation, the US Environmental Protection Agency (EPA) estimated the GHG emissions reduction related to the Brazilian sugarcane ethanol as 44\% (100 years, 2\% discount rate), including the effects due to land use change. The analysis was later revised for the Regulatory Impact Analysis, and aspects related to direct emissions as well as indirect effects were changed. Four scenarios were evaluated, considering pathways assuming most crop residue of the leaves as well as stalks would be collected (and therefore available for burning as process energy) or without the extra crop residue being neither collected nor burned as fuel. EPA also analyzed pathways assuming the ethanol is distilled in Brazil or alternatively being distilled in the Caribbean (CBI). The

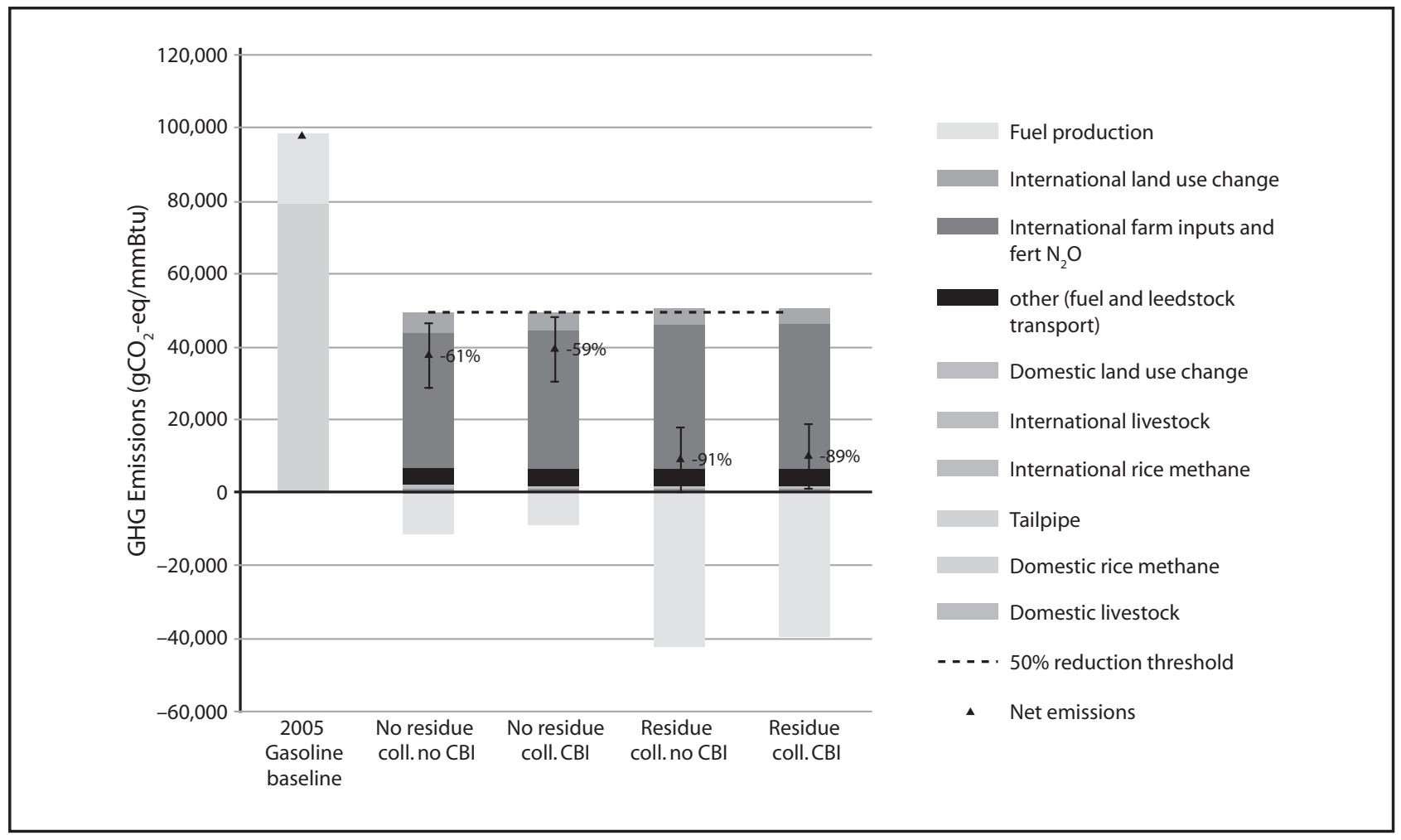

Source: EPA, 2010.

FIGURE 2 EPA results for sugarcane ethanol by lifecycle stage with and without residue collection and CBI. 
emissions reduction for these scenarios ranged between 59\% and 91\%, as indicated in Figure 2.

\section{ETHANOL AVOIDED EMISSIONS IN THE BRAZILIAN CONTEXT}

The contribution of sugarcane ethanol for GHG emissions mitigation in Brazil is substantial. Meira Filho and Macedo (2009) show that in 2006 the mitigation related to ethanol (and cogenerated electricity surplus) represented $22 \%$ of final emissions from the Transportation and Electricity sectors, and it could represent $43 \%$ in 2020 (see Figure 3). Total emissions in Brazil in 2006 (related to energy, production and use, in all sectors) were $350 \mathrm{Mt} \mathrm{CO}_{2} \mathrm{eq}$, and they are projected to reach $720 \mathrm{Mt} \mathrm{CO}_{2}$ eq in 2020 (EPE, 2007 apud Meira Filho and Macedo, 2009). Considering such values, the ethanol sector avoided the equivalent of $10 \%$ of 2006 emissions, and would be able to avoid 18\% in 2020.

In the current scenario, climate change may bring to the countries important adaptation costs; one option is to reduce the negative effects through emissions mitigation, which could lead to lower damages and adaptation costs. Recent

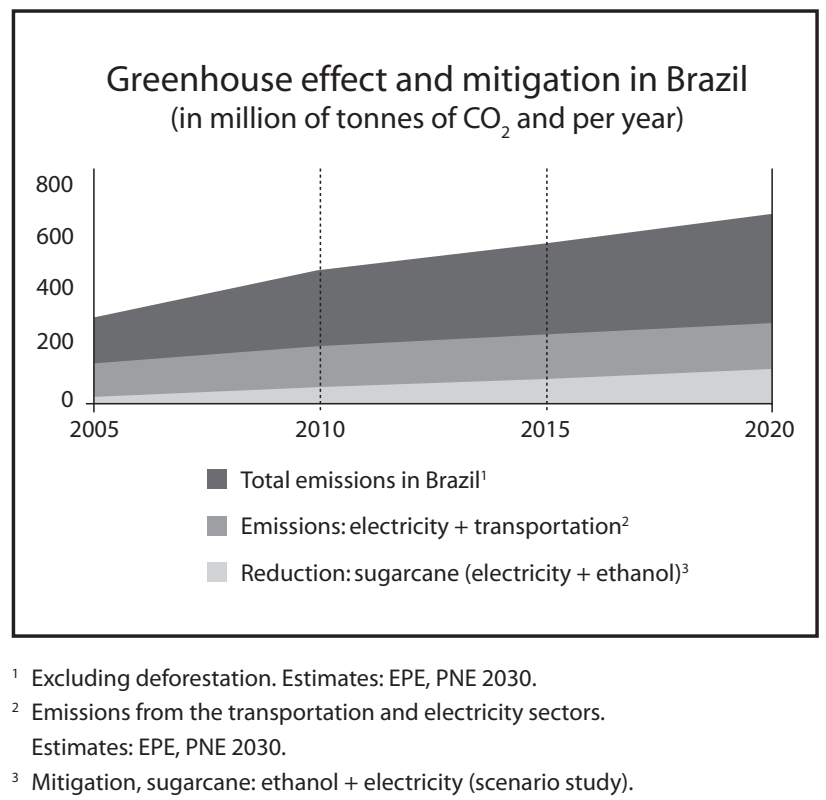

Source: SOUZA e MACEDO, 2009.

FIGURE 3 GHG emissions mitigation related to ethanol use in Brazil. analyses indicate the need to stabilize atmospheric $\mathrm{CO}_{2}$ concentration at $450 \mathrm{ppm}$. For such level, the mitigation costs could reach US $\$ 180$ per tonne of $\mathrm{CO}_{2}$ avoided between 2020 and 2030 (Souza and Macedo, 2009).

Meira Filho and Macedo (2009) estimated, thus, the mitigation cost related to the sugarcane ethanol, assuming the gasoline displacement and electricity surplus. Based on an average mitigation capacity of $2 \mathrm{t} \mathrm{CO}_{2} \mathrm{eq} / \mathrm{m}^{3}$ and a mitigation cost of US\$ 100 per tonne of $\mathrm{CO}_{2}$ eq, the authors calculated the additional value of ethanol as US $\$ 0.20$ per liter. This value (i.e. additional to the equivalent value of the displaced gasoline) represents one of the externalities of the ethanol use, which is not remunerated (internalized), but should be considered in the elaboration of policies to support ethanol production and use.

The use of biofuels worldwide may be an important tool to meet the emission targets established to control global warming. As an example, the effect on global temperature of the ethanol use in Brazil as a substitute for gasoline could be assessed. Meira Filho and Macedo (2009) estimated that the increase of planet's mean temperature would be $0.0004{ }^{\circ} \mathrm{C}$ higher in 2100 , if ethanol use remained at the same level of 1990. Similarly, the increase of the atmospheric $\mathrm{CO}_{2}$ concentration would be 0.05 ppm higher (see details in Meira Filho and Macedo (2009)).

\section{FINAL CONSIDERATIONS}

At present the use of cane ethanol as a substitute for gasoline represents one of the main options for GHG emissions mitigation. Despite the uncertainties related to the impacts of direct and (mainly) indirect land use change, it is not likely that the cane expansion in Brazil would lead to higher ethanol emissions, because of the combination of the relatively low demand for new areas and the great potential for areas release due to the conversion of low grade pasture (most of them degraded pasturelands). Regardless, this topic deserves intensive research efforts, aimed at the development of suitable methodologies and analysis tools, in addition to the collection/produc- 
tion of more accurate data on the carbon stocks for different crops and native vegetation.

$\mathrm{N}_{2} \mathrm{O}$ emissions derived from $\mathrm{N}$-fertilizers application and residues that are returned to the soil deserve special attention as well. Studies (e.g., Crutzen et al., 2008) suggest that emission factors provided by IPCC underestimate nitrous oxide emissions, and some experimental results pointed to the same direction for particular cases in specific regions (Allen et al., 2010; Denmead et al., 2009). However, it is important to note the huge variability of these emissions with respect to climate, soil, crop, tillage practices etc. Re-

\section{REFERENCES}

ALLEN, D. E.; KINGSTON, G.; RENNENBERG, H.; DALAL, R. C.; SCHMIDT, S. Effect of nitrogen fertilizer management and waterlogging on nitrous oxide emission from subtropical sugarcane soils. Agriculture, Ecosystems and Environment, 136: 209-217, 2010.

WAN, A.; MARINHO, J. P.; TARASANTCHI, R.; BEBER, A.; GIULIANI, E. Environmental sustainability of sugarcane ethanol in Brazil. In: ZUURBIER, P.; Van de VOOREN, J. (Eds.). Sugarcane ethanol, Wageningen Academic Publishers, Wageningen, the Netherlands, pp. 113-138, 2008.

BODDEY, R. M. Emissões de gases de efeito estufa na produção de bioetanol da cana-de-açúcar: o que sabemos e que falta saber. Embrapa Agrobiologia, Seropédica, RJ, 2009.

CARB. Detailed California-Modified GREET Pathways for Brazilian Sugarcane Ethanol: Average Brazilian Ethanol, With Mechanized Harvesting and Electricity Co-product Credit, With Electricity Co-Product Credit. Stationary Source Division. Release Date: July 20, 2009. Version 2.2.

CRUTZEN, P. J.; MOSIER, A. R.; SMITH, K. A.; WINIWARTER, W. N2O release from agro-biofuel production negates global warming reduction by replacing fossil fuels. Atmospheric Chemistry and Physics, 8: 389-395, 2008. DENMEAD, O. T.; MACDONALD, B. C. T.; BRYANT, G.; NAYLOR, T.; WILSON, S.; GRIFFITH, D. W. T.; WANG, W. J.; SALTER, B.; WHITE, I.; MOODY, P. W. Emissions of methane and nitrous oxide from Australian sugarcane soils. Agricultural and Forest Meteorology, doi:10.1016/j.agrformet.2009.06.018, 2009.

DIRECTIVE 2009/28/EC of the European Parliament and of the Council, of 23 April 2009, on the promotion of the use of energy from renewable sources and amending cent experimental analyses (Boddey, 2009) have showed that, for the Brazilian case, the emission factors would be even lower than those reported by IPCC.

Finally, cane ethanol co-products must be highlighted. Today the electricity surplus became a consolidated product of the cane mills, and a rapid growth is expected for the near future. Furthermore, as indicated in this work, as other more efficient technologies using sugarcane residual cane biomass are employed in the future, the environmental benefits related to the sugarcane products could be even greater.

and subsequently repealing Directives 2001/77/EC and 2003/30/EC. Official Journal of the European Union; L140/16; 05.06.2009.

EPA. Renewable Fuel Standard Program (RFS2) Regulatory Impact Analysis. Assessment and Standards Division, Office of Transportation and Air Quality, U. S. Environmental Protection Agency. EPA-420-R-10-006, February 2010.

EPE. Plano Nacional de Energia 2030. Empresa de Planejamento Energético, MME, 2007.

MACEDO, I. C. The sugarcane agro-industry and its contribution to reducing $\mathrm{CO}_{2}$ emissions in Brazil. Biomass and Bioenergy, 3 (2): 77-80, 1992.

MACEDO, I. C. Greenhouse gas emissions and energy balances in bio-ethanol production and utilization in Brazil (1996). Biomass and Bioenergy, 14 (1): 77-81, 1998.

MACEDO, I. C.; HORTA NOGUEIRA, L. A. Balanço de energia na produção de açúcar e álcool nas usinas cooperadas. Boletim Técnico Copersucar, v. 31/85, 1985.

MACEDO, I. C.; LEAL, M. R. L. V.; DA SILVA, J. E. A. R. Balanço das emissões de gases do efeito estufa na produção e no uso do etanol no Brasil. Secretaria do Meio Ambiente, Governo de São Paulo. 19 pp + anexos. Abril de 2004.

MACEDO, I. C.; SEABRA, J. E. A.; SILVA, J. E. A. R. Greenhouse gases emissions in the production and use of ethanol from sugarcane in Brazil: the 2005/2006 averages and a prediction for 2020. Biomass and Bioenergy, 32: 582-595, 2008.

MEIRA FILHO, L. G.; MACEDO, I. C. Etanol e mudança do clima: a contribuição para o PNMC e as metas para o pós-Kyoto. Versão preliminar. UNICA, São Paulo, Brasil, 2009. 
NASSAR, A. M.; RUDOR, B. F. T.; ANTONIAZZI, L. B.; ALVES DE AGUIAR, D.; BACCHI, M. R. P.; ADAMI, M. Prospects of the sugarcane expansion in Brazil: impacts on direct and indirect land use changes. In: ZUURBIER, P.; Van de VOOREN, J. (Eds.) Sugarcane ethanol, Wageningen Academic Publishers, Wageningen, the Netherlands, pp. 63-93, 2008.

RFA. Carbon and Sustainability Reporting Within the Renewable Transport Fuel Obligation: Technical Guidance Part Two Carbon Reporting - Default Values and Fuel Chains. Office of the Renewable Fuels Agency, V1.3. August 2008.

SEABRA, J. E. A. Avaliação técnico-econômica de opções para o aproveitamento integral da biomassa de cana no
Brasil. Campinas, Faculdade de Engenharia Mecânica, Universidade Estadual de Campinas, Tese de Doutorado, 273 p., 2008.

SILVA, J. G.; SERRA, G. E.; MOREIRA, J. R.; GONÇALVES, J. C.; GOLDEMBERG, J. Energy balance for ethyl alcohol production from crops. Science, 201 (4359): 903-906, 8 September 1978.

SOUZA, E. L.; MACEDO, I. C. (Coord). Etanol e Bioeletricidade: a cana-de-açúcar no futuro da matriz energética. União da Indústria da Cana-de-açúcar, São Paulo, Brasil, 2009. 